\author{
N. V. Popova ${ }^{1}$, V. I. Litvinenko², O. V. Kaidanska ${ }^{1}$, M. M. Boyko ${ }^{3}$, D. O. Alferova ${ }^{1}$ \\ ${ }^{1}$ National University of Pharmacy, Ukraine \\ ${ }^{2}$ State Scientific Center of Medicines, Ukraine \\ ${ }^{3}$ Belgorod National Research University, Russia
}

\title{
The analysis of serotonin derivatives from safflower seeds
}

Safflower, or American saffron, or wild saffron, or thistle (Carthamus tinctorius L.) is found both in the wild form as a weed and in the cultivated form. About 200 chemical components have been isolated from various organs of safflower, including coumarins, flavonoids, steroids, glycosides, pigments and fatty oils. To date, safflower is used as a dietary supplement with the antidiabetic, antihypertensive, antioxidant, anti-inflammatory, reparative and other types of activity. Taking into account the above-mentioned properties of the plant further pharmacognostic studies of safflower is relevant.

Aim. To analyze serotonin derivatives in domestic varieties of safflower.

Materials and methods. For the preliminary analysis of serotonin derivatives in the alcoholic extract from safflower seeds the paper and thin layer chromatographies (TLC and PC) were used. For further studies of the chemical composition of the alcoholic extract obtained the high-performance liquid chromatography reversed-phase, UV- and mass-spectroscopy were used.

Results and discussion. Using the preliminary chromatographic analysis (TLC and PC) of the safflower seed extracts two substances with an indole heterocycle were identified. On the chromatogram of the HPLC method two dominant substances were detected, for which the UV- and mass-spectra were determined. These compounds were identified as $\mathrm{N}$-feruloylserotonin and $\mathrm{N}$-cumaroylserotonin.

Conclusions. For the first time serotonin derivatives have been identified from seeds of domestic varieties of safflower.

Key words: safflower; $N$-feruloylserotonin; $N$-cumaroylserotonin

\author{
Н. В. Попова ${ }^{1}$, В. І. Литвиненко ${ }^{2}$, О. В. Кайданська ${ }^{1}$, М. М. Бойко ${ }^{3}$, Д. О. Алферова ${ }^{1}$ \\ ${ }^{1}$ Національний фрармацевтичний університет, Україна \\ 2 ДП «Державний науковий центр лікарських засобів», Україна \\ 3 Бєлгородський державний національний дослідницький університет, Росія
}

\section{Аналіз похідних серотоніну в насінні сафлору красильного}

Сафрлор красильний або американський шафран, або дикий шафран, або красильний чортополох (Carthamus tinctorius L.) зустрічається як у дикому вигляді як бур'ян, так і культивується. 3 різних органів сафрлору красильного виділено близько 200 хімічних компонентів, серед яких кумарини, фрлавоноїди, стероїди, глікозиди, пігменти та жирні олії. На теперішній час сафрлор красильний використовується в якості дієтичних добавок з антидіабетичною, антигіпертензивною, антиоксидантною, протизапальною, репаративною та іншими видами активності. 3 огляду на вищевказані властивості рослини подальші фармакогностичні дослідження сафлору красильного є актуальними.

Метою даної роботи був аналіз похідних серотоніну в спиртовому екстракті з насіння сафрлору красильного.

Матеріали та методи. Для попереднього аналізу похідних серотоніну в спиртовому екстракті з насіння сафрлору красильного використовували хроматографрію на папері та хроматографрію в тонкому шарі сорбенту. Для подальшого вивчення хімічного складу отриманого екстракту використовували метод високоефективної рідинної хроматографії з оберненою фазою, УФ- та мас-спектроскопією

Результати та їх обговорення. За допомогою попереднього хроматографічного аналізу (ТШХ та ПХ) екстрактів насіння сафлору красильного вдалося ідентифікувати дві речовини з індольним гетероциклом. На хроматограмі методу ВЕРХ були виявлені дві домінуючі речовини, для яких були встановлені УФ- та мас-спектри. Дані сполуки були ідентифіковані як N-фреруоїлсеротонін та N-кумароїлсеротонін.

Висновки. Вперше ідентифіковані похідні серотоніну у вітчизняних сортах насіння сафлору красильного.

Ключові слова: сафрлор красильний; N-фреруоїлсеротонін; N-кумароїлсеротонін

Н. В. Попова', В. И. Литвиненко², О. В. Кайданская', Н. Н. Бойко ${ }^{3}$, Д. А. Алфёрова'

${ }^{1}$ Национальный фармацевтический университет, Украина

2 ГП «Государственный научный центр лекарственных средств», Украина

${ }^{3}$ Белгородский государственный национальный исследовательский университет, Россия

\section{Анализ производных серотонина в семенах сафлора красильного}

Сафрлор красильный или американский шафран, или дикий шафран, или красильный чертополох (Carthamus tinctorius L.) встречается как в диком виде как сорняк, так и культивируется. Из различных частей сафлора красильного выделено около 200 химических компонентов, среди которых кумарины, фрлавоноиды, стероиды, гликозиды, пигменты и жирные масла. На сегодняшний день сафлор красильный используется в качестве диетических добавок с антидиабетической, антигипертензивной, антиоксидантной, противовоспалительной, репаративной и другими видами активности. Учитывая вышеуказанные свойства растения, дальнейшие фрармакогностические исследования сафлора красильного являются актуальными.

Целью данной работы был анализ производных серотонина в спиртовом экстракте из семян сафлора красильного. 
Материалы и методы. Для предварительного анализа производных серотонина в спиртовом экстракте из семян сафлора красильного использовали хроматографию на бумаге и хроматографию в тонком слое сорбента. Для дальнейшего изучения химического состава полученного экстракта использовали метод высокоэффективной жидкостной хроматографии с обращенной фразой, УФ- и масс-спектроскопией.

Результаты и их обсуждение. С помощью предварительного хроматографического анализа (ТCX и БХ) экстрактов семян сафолора красильного удалось идентифицировать два вещества с индольным гетероциклом. На хроматограмме метода ВЭЖХ было обнаружено два доминирующих вещества, для которых были установлены УФ- и масс-спектры. Данные соединения были идентифицированы как N-фреруоилсеротонин и $\mathrm{N}$-кумароилсеротонин.

Выводы. Впервые идентифицированы производные серотонина в отечественных сортах семян сафрлора красильного.

Ключевые слова: сафрлор красильный; N-фреруоилсеротонин; N-кумароилсеротонин

Introduction. Safflower (Carthamus tinctorius L.) is an annual or biennial plant from the family Asteraceae. Plants are to $150 \mathrm{~cm}$ tall. It is an oil-bearing crop wellknown in the world and Ukraine. A number of scientific and selection organizations of Ukraine are engaged in creation of varieties of this culture [1,2]. The plant attracts the attention due to the interesting composition of fatty oils of seeds, in which the share of linolenic acid accounts more than $70 \%$, as well as the flavonoid composition of flowers [1, 3].

Such class of compounds from seeds of safflower as serotonin derivatives (Fig. 1), which have a number of biological activities - from high antioxidant to analgesic and others, is also of interest $[4,5]$.

The aim of the work was to analyze serotonin derivatives in domestic varieties of safflower.

Materials and methods. The seeds of safflower were used for the analysis. The safflower was grown at the Botanical Garden of the National University of Pharmacy (NUPh). It was dried and standardized according to the requirements of GACP [6].

The seeds of safflower were ground to a particle size of $0.5-1 \mathrm{~mm}$, the exact weight of the raw material was collected, and the extraction was performed. It was initially treated with $\mathrm{n}$-hexane, then the extraction was performed with $70 \%$ alcohol $(1: 30)$. The extract obtained was used both for the preliminary chromatographic analysis and for chromatography-mass spectrometry.

For the preliminary analysis of serotonin derivatives the paper chromatography (Filtrak No. 11) and the thinlayer chromatography (Sorbfil, Merck plates) were used in the following solvent systems: hexane - acetone $(8: 2)$; butanol - acetic acid - water $(4: 1: 2) ; 15 \%$ acetic acid [7].

To detect the desired compounds the chromatograms were treated with reagents that were specific to the indole

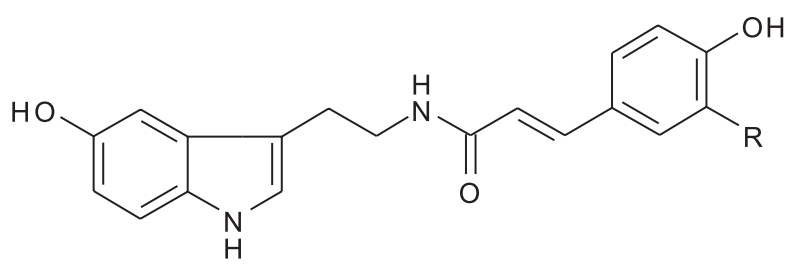

Fig. 1. The structural formulas of serotonin derivatives ( $\mathrm{R}=\mathrm{H}-\mathrm{N}$-feruloylserotonin; $\mathrm{R}=\mathrm{OCH}_{3}-\mathrm{N}$-cumaroylserotonin) heterocycle. After passing of solvents the TLC plates and paper chromatograms were studied in the visible and UV light before and after treatment with reagents [7].

The plant extracts obtained were analyzed by HPLC-MS in a liquid chromatograph system [8].

To study the chemical composition of the extract obtained the reversed-phase high-performance liquid chromatography was used. The chromatographic studies were performed on an "Agilent Technologies 1200 Infinity" chromatograph manufactured in the USA with an Agilent 1200 autosampler, a vacuum microdegassing device, a gradient pump and a thermostat of the same series. Electronic ranges of absorption were recorded using a spectrophotometric detector with an Agilent 1200 series diode array (the wavelength range from 200 to $400 \mathrm{~nm}$, a cuvette with an optical path length of $10 \mathrm{~mm}$, the volume of $13 \mathrm{mcl}$ ), the scanning step was $2 \mathrm{~nm}$. A more detailed method of analysis is described in [8].

The "Agilent Chem-Station" software was used for recording and processing spectral data and chromatograms.

The following solvents were used to prepare the mobile phases: ultrapure water (for liquid chromatography), ethyl alcohol $96 \%$ for medical purposes, formic acid.

Results and discussion. The preliminary chromatographic analysis (TLC and PC) of safflower seeds extracts allowed identifying at least two substances with an indole heterocycle. These compounds had blue fluorescence in UV light, which varied in ammonia vapors like hydroxycinnamic acids. The results of HPLC-MS analysis of the extracts of safflower seeds are presented in Fig. 2-4.

The HPLC chromatogram (Fig. 2) revealed two dominant substances (designated by us as FS - N-feruloylserotonin and CS - N-cumaroylserotonin), for which the UV and mass spectra shown in Fig. 2-4 were determined.

The above results regarding the UV-spectrum and the molecular weight in Fig. 3-4 for compounds FS and CS were in good agreement with the literature data. Thus, these compounds were identified as N-feruloylserotonin and $\mathrm{N}$-cumaroylserotonin.

Moreover, the results of the HPLC analysis of the ethanol extract showed that the relative area of $\mathrm{N}$-feruoylserotonin was $45.1 \%$, and for $\mathrm{N}$-cumaroylserotonin $40.6 \%$. 


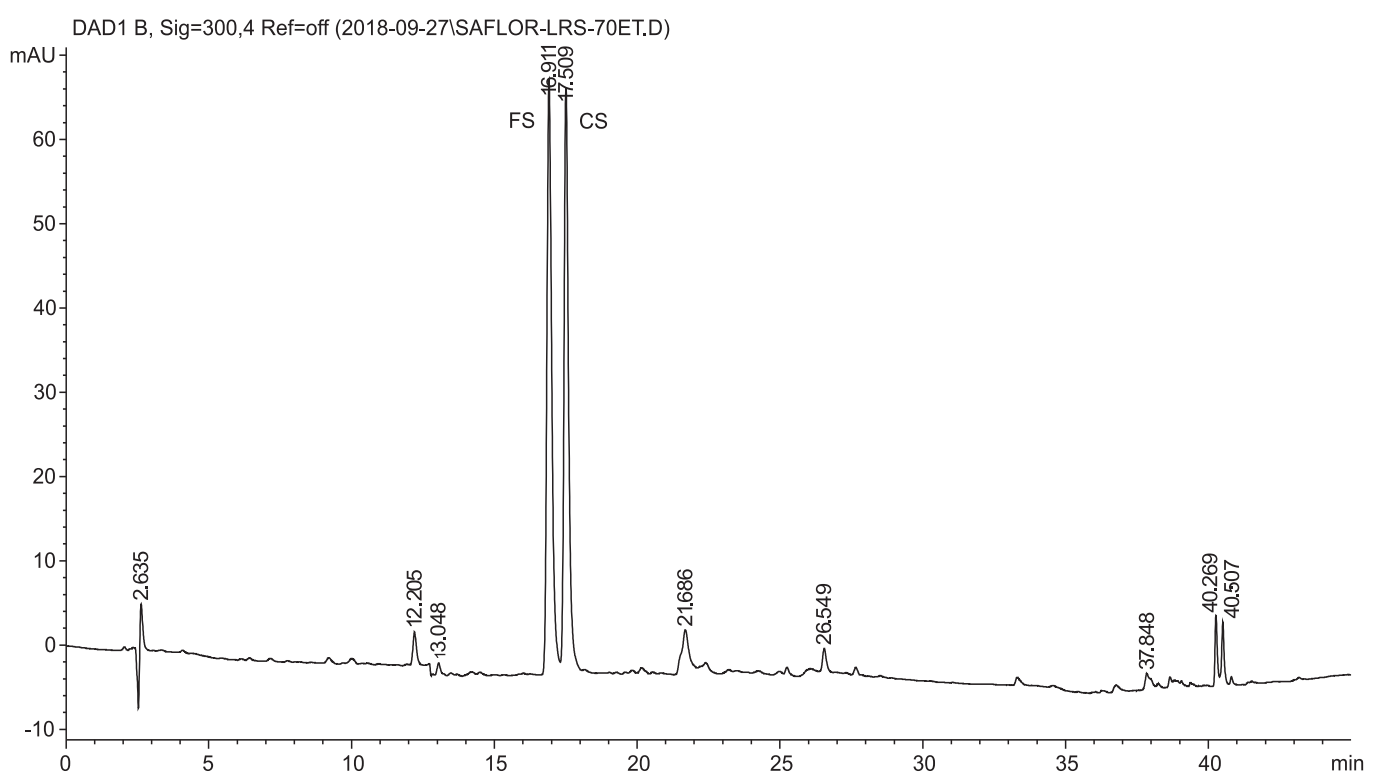

Fig. 2. The HPLC chromatogram of the ethanol extract of safflower seeds $(\lambda=300 \mathrm{~nm})$

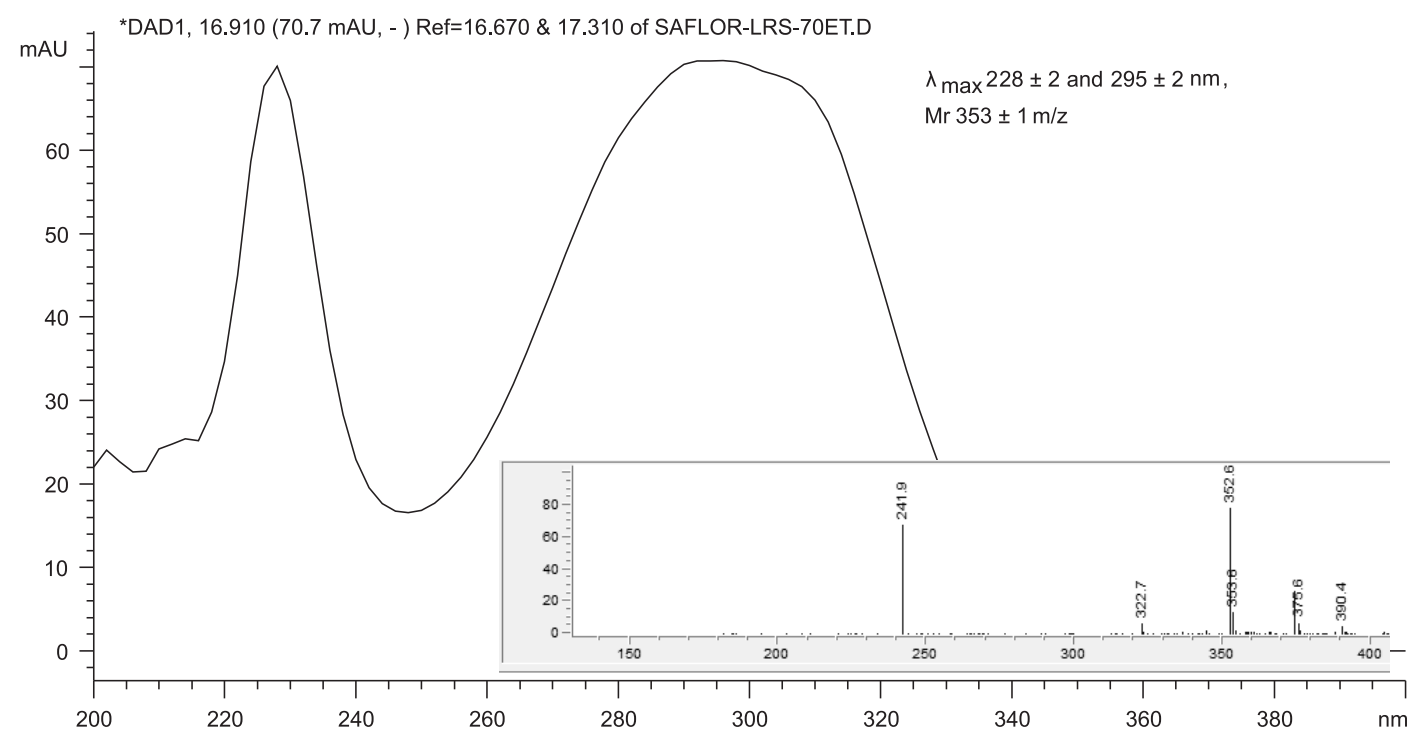

Fig. 3. The UV- and mass-spectrum of compound FS

*DAD1, $17.510(93.1 \mathrm{mAU},-$ ) Ref=17.310 \& 18.037 of SAFLOR-LRS-70ET.D

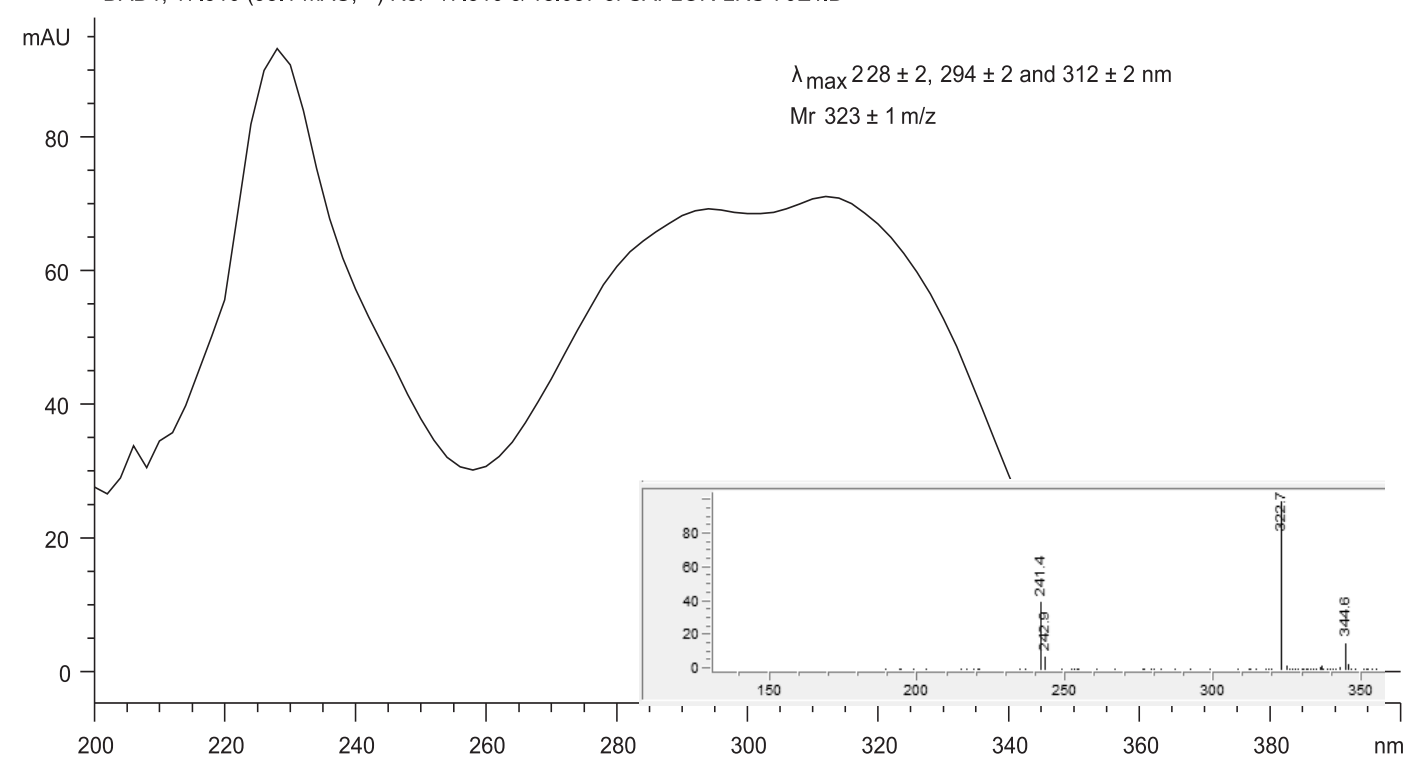

Fig. 4. The UV- and mass-spectrum of compound CS 
Conclusions and prospects for further research

1. For the first time the analysis of the composition of serotonin derivatives in domestic varieties of safflower seeds has been performed.
2. Two compounds $-\mathrm{N}$-feruloylserotonin and N-cumaroylserotonin have been identified.

Conflict of interests: authors have no conflict of interests to declare.

\section{REFERENCES}

1. Попова, Н. В. Лекарственные растения мировой флоры / Н. В. Попова, В. И. Литвиненко. - Х. : Диса-плюс, $2016 .-540$ с.

2. Барашовець, О.В.Дослідження різних груп фенольних сполук квіток сафлору красильного / О. В. Барашовець, Н. В. Попова // Фітотерапія. Часопис. - 2017. - № 1. - С. 39-42.

3. Рижій, сафлор, кунжут. Стратегія виробництва олійної сировини в Україні (малопоширені культури) / І. А. Шевченко, О. І. Поляков, К. В. Ведмедєва, І. Б. Комарова; Інститут олійних культур Національної академії аграрних наук України. - Запоріжжя : СТАТУС, 2017. - $40 \mathrm{c}$.

4. Preparative Separation of N-Feruloyl Serotonin and N- (p-Coumaroyl) Serotonin from Safflower Seed Meal Using High-Speed Counter-Current / Qiulong Zhang, Na Hu, Wencong Li et al. // Chromatography J. of Chromatographic Sci. - 2015. - Vol. 53 - P. $1341-1345$. https://doi.org/10.1093/chromsci/bmv018

5. Asgarpanah, J. Phytochemistry, Pharmacology and Medicinal Properties of Carthamus tinctorius L. / J. Asgarpanah, N. Kazemivash // Chin. J. Integr. Med. - 2013. - № 19 (2). - P. 153-159. https://doi.org/10.1007/s11655-013-1354-5

6. WHO guidelines on good agricultural and collection practices (GACP) for medicinal plants // World Health Organization Geneva 2003. $-72 \mathrm{p}$.

7. Шаршунова, М. Тонкослойная хроматография в фармации и клинической биохимии: в 2-х ч. / М. Шаршунова, В. Шварц, Ч. Михалец. - М. : Мир, 1980. - 622 с.

8. Studying the polyphenolic structure of Laurus Nobilis L. leaves / E. T. Zhilyakova, O. O. Novikov, D. I. Pisarev et al. // Indo Am. J. of Pharmac. Sci. - 2017. - № 4 (09). - P. 3066-3074. http://doi.org/10.5281/zenodo.910685

\section{REFERENCES}

1. Popova, N. V., Litvinenko, V. I. (2016). Lekarstvennye rasteniia mirovoi flory. Kharkov: Disa-plius, 540.

2. Barashovets, O. V., Popova, N. V. (2017). Fitoterapiia. Chasopys, 1, 39-42.

3. Shevchenko, I. A., Poliakov, O. I., Vedmedieva, K. V., Komarova, I. B. (2017). Ryzhii, saflor, kunzhut. Stratehiia vyrobnytstva oliinoi syrovyny $v$ Ukraini (maloposhyreni kultury). Instytut oliinykh kultur Natsionalnoi akademii ahrarnykh nauk Ukrainy. Zaporizhzhia: STATUS, 40.

4. Zhang, Q., Hu, N., Li, W., Ding, C., Ma, T., Bai, B., ... Ding, C. (2015). Preparative Separation of N-Feruloyl Serotonin and N-(pCoumaroyl) Serotonin from Safflower Seed Meal Using High-Speed Counter-Current Chromatography. Journal of Chromatographic Science, 53 (8), 1341-1345. https://doi.org/10.1093/chromsci/bmv018

5. Asgarpanah, J., \& Kazemivash, N. (2013). Phytochemistry, pharmacology and medicinal properties of Carthamus tinctorius L. Chinese Journal of Integrative Medicine, 19 (2), 153-159. https://doi.org/10.1007/s11655-013-1354-5

6. WHO guidelines on good agricultural and collection practices (GACP) for medicinal plants. (2003). Geneva: World Health Organization, 72.

7. Sharshunova, M., Shvartc, V., Mikhaletc, Ch. (1980). Tonkosloinaia khromatografia v farmatcii i klinicheskoi biokhimii. Moscow: Mir, 622.

8. Zhilyakova, E. T., Novikov, O. O., Pisarev, D. I., Malyutina, A. Y., Boyko, N. N. (2017). Studying the polyphenolic structure of Laurus Nobilis L. leaves. Indo American Journal of Pharmaceutical Sciences, 4 (09), 3066-3074. http://doi.org/10.5281/zenodo.910685

\section{Information about authors:}

Popova N. V., Doctor of Pharmacy (Dr. habil.), professor, head of the Department of Nutritiology and Pharmaceutical Bromatology, National University of Pharmacy. E-mail: bromatology@nuph.edu.ua

Litvinenko V. I., Doctor of Chemistry (Dr. habil.), professor, head of the Sector of Chemistry and Technology of Phenolic Medicines, State Scientific Center of Medicines

Kaidanska O. V., postgraduate student of the Department of Nutritiology and Pharmaceutical Bromatology, National University of Pharmacy

Boyko M. M., Candidate of Pharmacy (Ph.D.), associate professor of the Pharmaceutical Technology Department, Belgorod National Research University, Russia

Alferova D. O., Candidate of Pharmacy (Ph.D.), associate professor of the Department of Nutritiology and Pharmaceutical Bromatology, National University

of Pharmacy

Відомості про авторів:

Попова Н. В., д-р фармац. наук, професор, завідувач кафедри нутриціології та фармацевтичної броматології, Національний фармацевтичний університет. E-mail: bromatology@nuph.edu.ua

Литвиненко В. І., д-р хім. наук, професор, завідувач сектора хімії і технології фенольних препаратів ДП «ДНЦЛЗ»

Кайданська О. В., аспірант кафедри нутриціології та фармацевтичної броматології, Національний фармацевтичний університет

Бойко М. М., канд. фармац. наук, доцент кафедри фармацевтичної технології, Бєлгородський державний національний дослідницький університет, Росія

Алферова Д. О., канд. фармац. наук, доцент кафедри нутриціології та фармацевтичної броматології, Національний фармацевтичний університет

Сведения об авторах:

Попова Н. В., д-р фармац. наук, профессор, заведующая кафедрой нутрициологии и фармацевтической броматологии,

Национальный фармацевтический университет. E-mail: bromatology@nuph.edu.ua

Литвиненко В. И., д-р хим. наук, профессор, заведующий сектором химии и технологии фенольных препаратов ГП «ГНЦЛС»

Кайданская О. В., аспирант кафедры нутрициологии и фармацевтической броматологии, Национальный фармацевтический университет

Бойко Н. Н., канд. фармац. наук, доцент кафедры фармацевтической технологии, Белгородский государственный национальный исследовательский

университет, Россия

Алфёрова Д. А., канд. фармац. наук, доцент кафедры нутрициологии и фармацевтической броматологии, Национальный фармацевтический университет 